\title{
Performance evaluation of different observers in the interpretation of panoramic radiographs by the mandibular cortical index
}

\author{
Luciana Munhoz ${ }^{\mathrm{a}}$, Jun Ho Kimª, Moses Park ${ }^{\mathrm{a}}$, Eduardo Massaharu Aoki ${ }^{\mathrm{a}}$,
} Reinaldo Abdala Júnior ${ }^{\mathrm{a}}$, Emiko Saito Arita $^{\mathrm{a}}$

\begin{abstract}
OBJECTIVE: Mandibular Cortical Index (MCI) is useful in osteoporosis screening. This study aim was to verify the impact of different expertise levels in the observers' performances of $\mathrm{MCl}$ evaluation in panoramic radiographs (PR).

METHODS: Six participants were recruited: one Oral Radiology professor with previous experience (\#1), one master's degree student and radiologist with previous experience (\#2), one PhD student and non-radiologist with previous experience (\#3), one PhD student and radiologist with no prior experience (\#4) and two master's degree students with no prior experience (\#5 and \#6). Observers were trained to use the $\mathrm{MCl}$ before analyzing $150 \mathrm{PRs}$ of patients with dual energy X-ray absorptiometry (DXA) examination.

RESULTS: The Spearman's Correlation test showed inverse and weak to moderate correlation between $\mathrm{MCl}$ and T-scores, and it varied was according to the observe that performed the evaluation. Observers \#2 and \#3 (with previous $\mathrm{MCl}$ experience) showed the highest agreement with the professor, followed by students \#4, \#5 and \#6.

CONCLUSION: Students' expertise using the $\mathrm{MCI}$ increased the agreement with the professor regardless of whether the student was an oral radiology specialist; the $\mathrm{MCl}$ was correlated with the DXA in all the observer's evaluations, which indicates that previous training for the $\mathrm{MCl}$ can enable any dentist to apply it in osteoporosis screening.
\end{abstract}

Keywords: osteoporosis; bone mineral density; panoramic radiograph; professional performance.

\section{Avaliação da performance de diferentes observadores na interpretação do índice da cortical mandibular em radiografias panorâmicas}

\section{RESUMO}

OBJETIVO: O Índice Cortical Mandibular (ICM) é útil na triagem de pacientes com risco de osteoporose. O objetivo deste estudo foi verificar o impacto de diferentes níveis de conhecimento e formação no desempenho de observadores na aplicação do ICM em radiografias panorâmicas (RP)

MÉTODOS: Seis observadores participaram do experimento: uma professora de radiologia odontológica com experiência prévia na utilização do ICM (\#1), uma estudante de mestrado radiologista com experiência prévia na utilização do ICM (\#2), um estudante de doutorado não radiologista com experiência prévia na utilização do ICM (\#3), um estudante de doutorado radiologista sem experiência prévia (\#4) e dois estudantes de mestrado sem experiência prévia (\#5 e \#6). Os observadores foram orientados sobre como aplicar o ICM e posteriormente analisaram 150 RPs de pacientes com exame de densitometria óssea (DXA).

RESULTADOS: O teste de correlação de Spearman mostrou correlação inversa e fraca à moderada entre o ICM e o DXA, variando dependendo do observador que realizou a avaliação. Os observadores \#2 e \#3 (com experiência prévia) mostraram maior concordância com a professora, seguido dos alunos \#4, \#5 e \#6.

CONCLUSÃO: A experiência dos alunos com o ICM aumentou a concordância com a professora, independentemente de $\mathrm{o}$ aluno ser um especialista em radiologia oral; o ICM apresentou correlação com o DXA para todos os observadores, o que indica que a informação prévia sobre o uso do ICM pode permitir que qualquer dentista aplique-o na detecção de pacientes com risco de desenvolvimento de osteoporose.

Palavras-chave: Osteoporose, Densidade mineral óssea, Radiografia panorâmica, Performance profissional. a Department of Stomatology, School of Dentistry, University of São Paulo (USP), São Paulo, Brazil

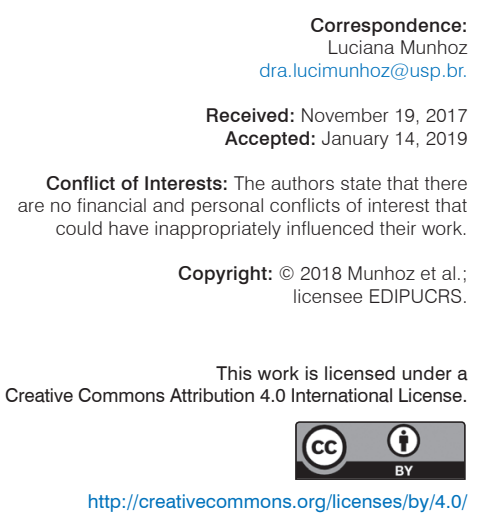

http://creativecommons.org/licenses/by/4.0/ 


\section{INTRODUCTION}

Osteoporosis is an osteometabolic disease of chronic and systemic characteristics. Its progression results in the deterioration of bone microarchitecture and reduction of the bone mineral density (BMD) [1]. Osteoporosis affects mostly postmenopausal women [2], although it can also affect men [3] and patients with diseases in the bone metabolism [4]. The main consequences of osteoporosis are osteoporotic or low-impact fractures [5], whose more frequent sites are the hip and the forearm [6], Such fractures can progress to morbidity and mortality, and it represents high costs to the health system [7].

Currently, the most reliable tool for diagnosis of osteoporosis is the DXA examination which shows quantitative measurement of BMD [8]. However, considering the high cost of the exam, it is not always accessible in many countries $[9,10]$. Thus, many patients with risk of osteoporosis are not properly diagnosed or treated. A bone fracture can be considered an osteoporosis signal, but, when it occurs, it comes down to the diagnosis done belatedly [11]. Therefore, screening tools for osteoporosis were developed to identify potential individuals that need to be referred for DXA exam [12].

On the other hand, dental surgeons frequently request PRs for patients who initiate dental treatments $[13,14]$ as a complementary exam to the initial diagnosis and/ or for case follow-ups [15]. PR is a low-cost and accessible exam [16]. Studies show that it may indicate osteoporotic changes in the mandible [17], notably morphological alterations in the mandibular cortex [18]. Because of that, several radiomorphometric indexes were developed [17,19] and among them, the MCI is highlighted [18].

The MCI is a qualitative index and was developed by Klemetti et al. in 1994 [18]. It evaluates morphological features (lacunar and linear erosions) of the endosteal margin and inferior cortex on the mandible that goes from the region of the mental foramen to the region of the lower second molars. Currently, the MCI is reported in the literature as a highly useful index in the screening of osteoporosis [1, 19-23].
The index proposed by Klemetti [18] consists of the following classification for the endosteal margin of the mandible:

- C1: well delimited and demarcated endosteal margin with absence of radiolucent defects in lacunar or/and rectilinear morphology indicates erosions and signals patients with no need for the DXA exam;

- C2: endosteal margin presenting lacunar defects or moderate radiolucent rectilinear defects evidences the possibility of reduced BMD (or osteopenia) and the need for further investigation using the DXA;

- C3: endosteal margin and mandibular cortex severely eroded with multiple semilunar or linear defects strongly suggests a patient with osteoporosis and the need for a DXA exam.

The MCI is easy to apply and does not require the use of any calculations, software, or specific programs for its execution; however, it is an index that requires good acuity and visual perception by the observer. Thus, previous orientation for the dental surgeon is necessary to apply it correctly [24-27]. It is known that professionals of different occupational fields and experience with the MCI shows distinct sensibility for its application. Therefore, this study aims to assess the MCI evaluation concordance level when used by professionals of different areas with and without previous experience with the index and its correlation with the DXA.

\section{METHODS}

\section{Observers and orientations}

Six observers participated in this study: one university professor in oral radiology with previous experience using the MCI (\#1); one radiologist, post-graduation student, with previous experience using the $\mathrm{MCI}(\# 2)$; one non-radiologist, post-graduation student with previous experience using the MCI (\#3); one radiologist, post-graduation student with no prior experience using the MCI (\#4) and two master's degree students with no prior experience using the $\mathrm{MCI}$ (\#5 and \# 6).

Initially, observers received basic information about the index and a didactic scheme based on the original article [20] as described in Figure 1.

\section{C1}
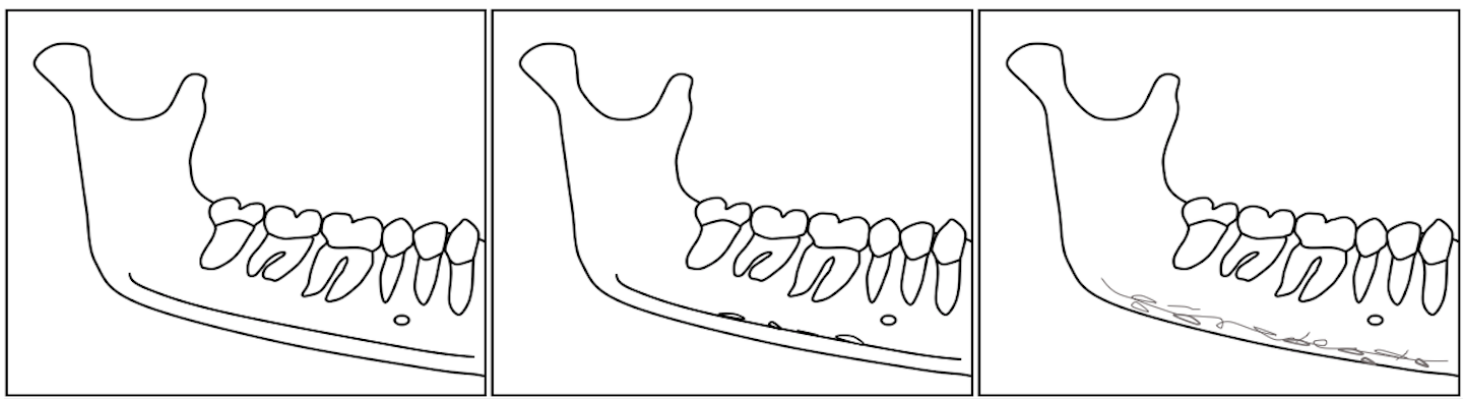

Figure 1. Schematic picture of mandibular cortical index for didactic purposes, based in the design of the developers [18]. 

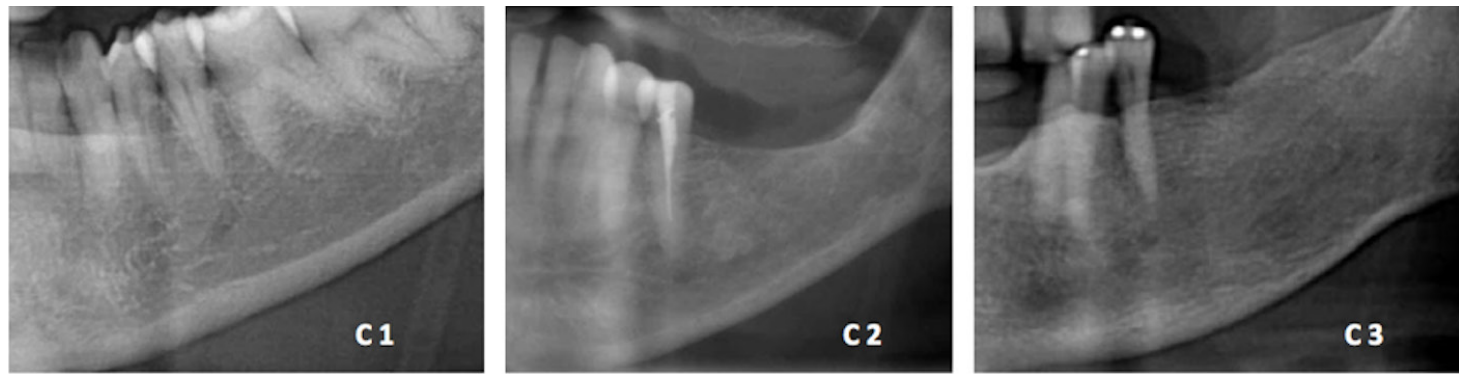

Figure 2. Example of radiographs showed to the participants aiming the orientations about the $\mathrm{MCl}$

Secondly, the participants received examples of MCI classification and were able to discuss among themselves the particular impressions and conclusions of each radiograph. In Figure 2, examples of images used in the discussion are shown. Sequentially, they applied the MCI to evaluate the mandibular endosteal margin of 150 PRs.

\section{Subjects}

A total of 150 PRs were assessed. Radiographs presenting technical problems such as positioning errors, lesions, or anatomical variations in the region of interest were excluded. The selected radiographs were done in patients who participated in The Osteoporosis Prevention Week at the Dentistry School of the University of Sao Paulo. The event occurred in distinct weeks between the years of 2010 and 2014, offering screening examinations for osteoporosis. Patients signed a free and informed consent term, performed PR to start dental treatment in the Dentistry School and peripheral forearm DXA was done in the same day. Data collection was carried out with the approval of the ethics committee (FR358902 145/10). All PRs were performed using the same device (Kodak 8000, Eastman Kodak Company, Rochester, USA) and the peripheral DXAs were also performed using the same device (pDEXA, Norland, Norland Medical Systems, Inc., White Plains, New York, United States of America).

\section{DXA assessment}

For statistical purposes, values of the peripheral DXA of the proximal radius were used, following the range values of BMD (T-score) determined by the World Health Organization (WHO) [28]:

$>-1,0$ : Normal BMD

$<-1.0$ e $>-2.49$ : Low BMD (Osteopenia)

$<-2.5$ : Osteoporosis

For MCI analysis, the 150 selected radiographs were classified by the observers in a dark environment with controlled illumination. The Weighted Kappa test was used to check the interobservers' agreement, considering the university professor as the gold standard to MCI evaluation. The Spearman's correlation test was performed to verify the correlation between the DXA exam and the MCI. All the statistical analysis was performed by IBM SPSS Statistics 24 (SPSS, Inc, Chicago, IL, United States of America).

\section{RESULTS}

A total of 150 PRs were assessed. The Weighted Kappa test, by comparing each student's MCI assessment with the university professor (\#1), showed higher agreement with observers \#2, $\mathrm{K}_{\mathrm{w}} 0.954$ (95\% confidence interval [CI], 0.90-0.99), and \#3, $\mathrm{K}_{\mathrm{w}} 0.584$ (95\% [CI], 0.46-0.70), and low agreement with student $\# 6, \mathrm{~K}_{\mathrm{w}} 0.272(95 \%$ [CI], 0.17-0.36) considering the statistical significance of the difference set at $\mathrm{p}<0.05$ as described in Table $\mathbf{1}$.

An inverse correlation was observed between the peripheral DXA values and the MCI values of each observer $(p<0.001)$. In addition, a strong correlation was set considering the proximity of the $\mathrm{R}_{\mathrm{s}}$ value of observers with $\mathrm{R}_{\mathrm{S}}$ value of the more MCI experienced observer \#1, while weaker correlation was set for those who had less previous experience with the MCI, as described in Table 2.

Table1. Interobserver agreement - Weighted Kappa test

\begin{tabular}{lccc}
\hline Weighted Kappa & & p value & IC* $-95 \%$ \\
Observer 1 x Observer 2 & 0.954 & 0.000 & $0.909-0.999$ \\
Observer 1 x Observer 3 & 0.584 & 0.000 & $0.464-0.704$ \\
Observer 1 x Observer 4 & 0.417 & 0.000 & $0.302-0.532$ \\
Observer 1 x Observer 5 & 0.368 & 0.000 & $0.256-0.481$ \\
Observer 1 x Observer 6 & 0.272 & 0.000 & $0.178-0.366$ \\
\hline
\end{tabular}

${ }^{*} \mathrm{Cl}$ - Confidence Interval.

Table 2. Spearman's Correlation test - Between the peripheral DXA values and the $\mathrm{MCl}$ values

\begin{tabular}{lcccccc}
\hline \multicolumn{7}{c}{ Non-parametric - Spearman's Correlation } \\
Observer & $\# 1$ & $\# 2$ & $\# 3$ & $\# 4$ & $\# 5$ & $\# 6$ \\
Coefficient $r_{s}$ & $-0.532^{*}$ & $-0.490^{*}$ & $-0.463^{*}$ & $-0.404^{*}$ & $-0.363^{* a}$ & $-0.313^{* a}$ \\
\hline * The correlation is significant with level $p<0,05$. \\
a Weak correlation.
\end{tabular}

\section{DISCUSSION}

Radiomorphometric indexes, such as the MCI, were developed to use PRs in the detection of patients that 
need to do DXA exams $[17,18]$. The MCI is an index of easy applicability; however, previous experience with its particularities positively affects the adequate application as a screening tool for patients that are susceptible to osteoporosis [24]. This study verified that professionals with previous experience using this index are more competent to detect patients with decreased BMD. However, professionals without previous experience using the MCI but with previous orientations about the index were also able to screen patients with low BMD.

Similar results were observed in previous studies in which general dental surgeons received orientation for the MCI and applied it to the screening of patients that needed to be referred for a DXA exam. As well, such professionals were able to identify patients with low BMD $[5,24,29]$. However, in a study with a reduced number of observers (three), an inability to correlate the DXA results with the MCI was verified [30].

Another previous finding was the higher correlation between the MCI and the DXA exam by previously oriented radiologists when compared to non-radiologist dentists $[24,29]$. In the present study, we observed a similar result: observer \#4 (a radiologist with no previous experience using the MCI) had a better agreement with observer \#1 (a university professor with previous experience using the $\mathrm{MCI})$ as well as a stronger correlation between the MCI and the DXA exam than the observers \#5 and \#6 (nonradiologists with no previous experience using the MCI). This greater facility in MCI application may be because radiologists are trained to interpret radiographs [24,31] and are able to verify details in radiographs with greater acuity.

The agreement between the observers, when compared to observer \#1 who was considered the most qualified in MCI assessment, showed significant variations. The lower agreement with \#1 was the correlation between the DXA exam and the MCI. This may indicate that the practice of using the MCI improves the results. [25] Among the most experienced observers ( $\# 2$ and $\# 3$ ), the radiologist observer (\#2) presented the highest agreement with \#1 and a more significant correlation when compared to \#1. This fact demonstrates that the combination of previous experience and expertise in radiology can improve the application of the MCI.

\section{CONCLUSION}

Finally, according to the results of this study, we concluded that the MCI could and should be used by dentists, regardless their specialties. Professionals could be oriented to screen osteoporosis in PRs and refer their patients for DXA exams when necessary, achieving an early diagnosis in case of BMD reduction, and consequently, decreasing the risk of osteoporotic fractures, the main deleterious outcome of osteoporosis. Yet, what we have found is more experienced practitioners with the MCI present more facility in detecting patients with low BMD.

\section{REFERENCES}

1. Kim OS, Shin MH, Song IH, Lim IG, Yoon SJ, Kim OJ, et al. Digital panoramic radiographs are useful for diagnosis of osteoporosis in Korean postmenopausal women. Gerodontology 2016;33(2):185-92. https://doi. org/10.1111/ger.12134

2. Zhao R. Immune regulation of bone loss by Th17 cells in oestrogendeficient osteoporosis. Eur J Clin Invest 2013;43(11):1195-202. https:// doi.org/10.1111/eci.12158

3. Bliuc D, Nguyen ND, Milch VE, Nguyen TV, Eisman JA, Center JR. Mortality risk associated with low-trauma osteoporotic fracture and subsequent fracture in men and women. JAMA 2009;301(5):513-21. https://doi. org/10.1001/jama.2009.50

4. Palermo A, D'Onofrio L, Buzzetti R, Manfrini S, Napoli N. Pathophysiology of Bone Fragility in Patients with Diabetes. Calcif Tissue Int 2017;100(2):12232. https://doi.org/10.1007/s00223-016-0226-3

5. Nakamoto T, Taguchi A, Ohtsuka M, Suei Y, Fujita M, Tanimoto K, et al Dental panoramic radiograph as a tool to detect postmenopausal women with low bone mineral density: untrained general dental practitioners diagnostic performance. Osteoporos Int 2003;14(8):659-64. https://doi. org/10.1007/s00198-003-1419-y

6. Halling A, Persson GR, Berglund J, Johansson O, Renvert S. Comparison between the Klemetti index and heel DXA BMD measurements in the diagnosis of reduced skeletal bone mineral density in the elderly. Osteoporos Int 2005;16(8):999-1003. https://doi.org/10.1007/s00198004-1796-X

7. Dutra V, Yang J, Devlin H, Susin C. Radiomorphometric indices and their relation to gender, age, and dental status. Oral Surg Oral Med Oral Pathol Oral Radiol Endod 2005;99(4):479-84. https://doi.org/10.1016/i. tripleo.2004.09.013

8. Pisani P, Renna MD, Conversano F, Casciaro E, Muratore M, Quarta E, et al. Screening and early diagnosis of osteoporosis through $\mathrm{X}$-ray and ultrasound based techniques. World J Radiol 2013;5(11):398-410. https:// doi.org/10.4329/wjr.v5.i11.398

9. Mithal A, Bansal B, Kyer CS, Ebeling P. The Asia-Pacific Regional AuditEpidemiology, Costs, and Burden of Osteoporosis in India 2013: A report of International Osteoporosis Foundation. Indian J Endocrinol Metab 2014;18(4):449-54. https://doi.org/10.4103/2230-8210.137485

10. Kanis JA, Johnell O. Requirements for DXA for the management of osteoporosis in Europe. Osteoporos Int 2005:16(3):229-38. https://doi. org/10.1007/s00198-004-1811-2

11. Nguyen TV, Center JR, Eisman JA. Osteoporosis: underrated, underdiagnosed and undertreated. Med J Aust 2004;180(5 Suppl):S18-22

12. Schwartz EN, Steinberg DM. Prescreening tools to determine who needs DXA. Curr Osteoporos Rep 2006;4(4):148-52. https://doi.org/10.1007/ s11914-996-0023-4

13. Taguchi A. Triage screening for osteoporosis in dental clinics using panoramic radiographs. Oral Dis 2010:16(4):316-27. https://doi. org/10.1111/j.1601-0825.2009.01615.x

14. Gulsahi $A$, Yüzügüllü $B$, Imirzalioglu $P$, Genç Y. Assessment of panoramic radiomorphometric indices in Turkish patients of different age groups, gender and dental status. Dentomaxillofac Radiol 2008;37(5):288-92. https://doi.org/10.1259/dmfr/19491030

15. Devlin $\mathrm{H}$, Whelton $\mathrm{C}$. Can mandibular bone resorption predict hip fracture in elderly women? A systematic review of diagnostic test accuracy Gerodontology 2015;32(3):163-8. https://doi.org/10.1111/ger.12077

16. Gomes CC, de Rezende Barbosa GL, Bello RP, Bóscolo FN, de Almeida SM. A comparison of the mandibular index on panoramic and crosssectional images from CBCT exams from osteoporosis risk group Osteoporos Int 2014;25(7):1885-90. https://doi.org/10.1007/s00198-014. 2696-3

17. Taguchi A, Suei Y, Sanada M, Ohtsuka M, Nakamoto T, Sumida H, et al. Validation of dental panoramic radiography measures for identifying postmenopausal women with spinal osteoporosis. AJR Am J Roentgenol 2004;183(6):1755-60. https://doi.org/10.2214/ajr.183.6.01831755

18. Klemetti E, Kolmakov S, Kröger H. Pantomography in assessment of the osteoporosis risk group. Scand J Dent Res 1994;102(1):68-72. https:// doi.org/10.1111/j.1600-0722.1994.tb01156.x

19. Valerio CS, Trindade AM, Mazzieiro ET, Amaral TP, Manzi FR. Use of digital panoramic radiography as an auxiliary means of low bone mineral density detection in post-menopausal women. Dentomaxillofac Radiol 2013;42(10):20120059. https://doi.org/10.1259/dmfr.20120059

20. Munhoz L, Cortes AR, Arita ES. Assessment of osteoporotic alterations in type 2 diabetes: a retrospective study. Dentomaxillofac Radiol 2017: doi: 10.1259/dmfr.20160414. https://doi.org/10.1259/dmfr.20160414 
21. Bhatnagar S, Krishnamurthy V, Pagare SS. Diagnostic efficacy of panoramic radiography in detection of osteoporosis in post-menopausal women with low bone mineral density. J Clin Imaging Sci 2013;3:23. https://doi.org/10.4103/2156-7514.113140

22. Erdogan O, Incki KK, Benlidayi ME, Seydaoglu G, Kelekci S. Dental and radiographic findings as predictors of osteoporosis in postmenopausal women. Geriatr Gerontol Int 2009;9(2):155-64. https://doi.org/10.1111/ j.1447-0594.2009.00518.x

23. Marandi S, Bagherpour A, Imanimoghaddam M, Hatef M, Haghighi A. Panoramic-based mandibular indices and bone mineral density of femoral neck and lumbar vertebrae in women. J Dent (Tehran) 2010;7(2):98-106.

24. Taguchi A, Asano A, Ohtsuka M, Nakamoto T, Suei Y, Tsuda M, et al Observer performance in diagnosing osteoporosis by dental panoramic radiographs: results from the osteoporosis screening project in dentistry (OSPD). Bone 2008;43(1):209-13. https://doi.org/10.1016/j. bone.2008.03.014

25. Jowitt N, MacFarlane T, Devlin H, Klemetti E, Horner K. The reproducibility of the mandibular cortical index. Dentomaxillofac Radiol 1999;28(3):141-4. https://doi.org/10.1038/sj.dmfr.4600427

26. Shintaku WH, Enciso R, Covington JS, Migliorati CA. Can dental students be taught to use dental radiographs for osteoporosis screening? J Dent Educ 2013;77(5):598-603.
27. Devlin CV, Horner $\mathrm{K}$, Devlin $\mathrm{H}$. Variability in measurement of radiomorphometric indices by general dental practitioners. Dentomaxillofac Radiol 2001;30(2):120-5. https://doi.org/10.1038/sj.dmfr.4600594

28. Assessment of fracture risk and its application to screening for postmenopausal osteoporosis. Report of a WHO Study Group. World Health Organ Tech Rep Ser 1994;843:1-129.

29. Taguchi A, Ohtsuka M, Nakamoto T, Naito K, Tsuda M, Kudo Y, et al. Identification of post-menopausal women at risk of osteoporosis by trained general dental practitioners using panoramic radiographs. Dentomaxillofac Radiol 2007;36(3):149-54. https://doi.org/10.1259/dmfr/31116116

30. Amorim MA, Takayama L, Jorgetti V, Pereira RM. Comparative study of axial and femoral bone mineral density and parameters of mandibular bone quality in patients receiving dental implants. Osteoporos Int 2007;18(5):703-9. https://doi.org/10.1007/s00198-006-0295-7

31. Taguchi A, Tanimoto K, Suei Y, Otani K, Wadamoto M, Akagawa Y, et al. Observer agreement in the assessment of mandibular trabecular bone pattern from panoramic radiographs. Dentomaxillofac Radio 1997;26(2):90-4. https://doi.org/10.1038/sj.dmfr.4600213 